University of Warwick institutional repository: http://go.warwick.ac.uk/wrap This paper is made available online in accordance with publisher policies. Please scroll down to view the document itself. Please refer to the repository record for this item and our policy information available from the repository home page for further information.

To see the final version of this paper please visit the publisher's website. Access to the published version may require a subscription.

Author(s): Floyd, Rita

Article Title: The Environmental Security Debate and its Significance for Climate Change

Year of publication: 2008

Link to published version:

http://dx.doi.org/ 10.1080/03932720802280602

Publisher statement: None 


\title{
The Environmental Security Debate and Its Significance for Climate Change
}

\author{
Rita Floydｒitataureck@hotmail.com
}

Rita Floyd is ESRC Post-doctoral Fellow at the University of Warwick and Associate Fellow at the Institute for Environmental Security. The author would like to thank the two anonymous reviewers for their helpful comments, as well as Jonathan Floyd for numerous useful conversations about this article.

Environmental security emerged as both a concept and a set of policies as a consequence of the end of the Cold War. As a corollary of this, new debates were simultaneously opened up regarding the nature of the threat, the appropriate referent object of security and also the meaning of security itself. There was, at the same time and for the same reason, a need for a new set of "discourses of danger" on the part of the United States security establishment. Environmental security quickly became one of the more prominent issues in this new era of security studies. Although currently sidelined by "the war on terror", the possible linkage between global warming and security gives renewed fervour to the environmental security debate. The present article both revisits this debate and considers its significance for securitising the climate; that is, making climate change a security issue.

\section{Early advocates}

Within the International Relations' sub-discipline security studies, security is regarded as being an "essentially contested concept". ${ }^{1}$ The contestedness of security arises as a function of the fact that the meaning of security is not an ontological given, but changes across time. ${ }^{2}$ Since security has no constant meaning, the concept means something different for every tradition within security studies. Consequently different traditions within security studies conceive very differently of environmental security; differing vastly in terms of who or what is to be secured, what is to be secured against and also the nature of the threat itself. As a result, environmental security is not so much a concept as it is a debate, with different approaches to environmental security at odds with one another.

I ___ Although environmental security came into its own with the end of the Cold War, a select number of writers had called for the redefinition of national security to include environmental issues well before that time. Writing in 1983, International Relations' scholar Richard Ullman, for example, argued for the redefinition of national security to include raw material shortages as well as natural disasters. ${ }^{3}$ Although in Ullman's view there was little doubt about the rightful place of environmental issues on the national security agenda, he realised that in the military climate of the Cold War such a redefinition would be difficult to achieve and must commence with enhanced public education about the threat potential of an ill-

\footnotetext{
${ }^{1}$ Walter B. Gallie cited in Buzan, People, States and Fear, 7.

${ }^{2}$ Wæver, "Peace and Security".

${ }^{3}$ Ullman, "Redefining Security",19.
} 
functioning environment. Arguably such public education was offered by the mostly descriptive works of the prominent environmental scientist Norman Myers ${ }^{4}$ and then Vice President of the World Resources Institute Jessica Tuchman Mathews, ${ }^{5}$ who painted bleak pictures about the state of the environment and even bleaker ones of possible future scenarios and on that basis called for the widening of national security to include environmental issues. This focus on national security is especially interesting because these writers were actually so broad in their interpretation of environmental security that they can easily be positioned within the human security discourse on environmental security. The reasons why they chose to advocate environmental security as a national security issue instead, is that most of them realised that their voices were more likely to be heard if they remained within the traditional state-centric reading of security. ${ }^{6}$

\section{The military and environmental security}

Another prominent writer on environmental issues that clearly realised this need for remaining with the tradition is Arthur Westing. Westing, himself convinced that environmental security is a component of human security (the other being political security) ${ }^{7}$ focuses in the vast majority of his writings on the detrimental role of the military on the natural environment, both during the conduct of war and in preparation for war. Compared to the short history of environmental security, this approach has a long tradition and dates back to the 1960s and US engagement of environmental warfare in the Vietnam conflict. Environmental warfare refers to the planned destruction of the natural environment - be it through herbicides, chemical bombs/agents, concussion bombs, forest fires or deliberate salinisation of arable land or freshwater reservoirs, for example, by breaking dams - as an important part of the overall military strategy. Outside of warfare, this approach criticises the environmental misconduct of the military in training or in preparation for war which, during the Cold War led to the toxic contamination of military bases and their surrounding areas, as well as groundwaters and rivers throughout the US. Westing's focus on the role of the traditional security institution in the systematic destruction of the natural environment is thus not only narrow in its focus, but has considerable purchase as a critique of the armed forces.

I This was never more evident than at the end of the Cold War when both the US Department of Energy (DoE) and the Department of Defense (DoD) came under increasing pressure from public opinion for their environmental misconduct. In response to these developments, select members of Congress, including Al Gore, became increasingly interested in reversing the military's negative role and began to promote the military as a good steward of the environment. This move was not as selfless as it may seem, rather the DoD was concerned with creating environmental conditions that could impair its ability to prepare for or carry out the National Security Strategy. ${ }^{8}$ In addition, with the superpower conflict over, all security institutions were hard pressed to find new "discourses of danger" " that would provide them with

\footnotetext{
${ }^{4}$ Myers, "Environment and Security", throughout

${ }^{5}$ Tuchman Mathews, "Redefining Security", throughout

${ }^{6}$ Dabelko, Tactical Victories and Strategic Losses..4.

${ }^{7}$ Westing, "The Environmental Component of Comprehensive Security”,129.

${ }^{8}$ Goodman, Military capabilities related to Environmental Security, 98.

${ }^{9}$ Campbell, Writing Security, 170.
} 
raisons d'être and thus secure funding. ${ }^{10}$ Consequently, the idea that unique military capabilities, such as the means of the defence intelligence community, could be used to "analyse, predict and ameliorate international environmental problems"11 was a welcome proposal, and with it, as Ronald J. Deibert has called it, the "military environmental security complex" was born. ${ }^{12}$

I _ This said, there is no question that the US defence environmental security strategy (also known as the greening of defence) has had a number of positive outcomes, including, amongst other things, the creation of a stable $\$ 5$ billion dollar annual budget (from 1994-2000), the introduction of a pollution prevention strategy in 1994 and successful cleanup missions abroad. Notable here, in particular, is the US led clean-up and storage of spent nuclear fuel in the Murmansk area under the Arctic Military Environmental Cooperation (AMEC) programme. On the other hand, there is little doubt that in the domestic realm defence environmental security was largely tantamount to compliance with already existing federal, state and international environmental legislation that offered little of truly novel value. ${ }^{13}$ In part because of this defence environmental security has been heavily criticised. Environmentalists and many within the security community were against the linkage of the military with the environment from the start, the standard argument being that such a linkage may lead to the militarisation of the environment, the process whereby environmental security simply refers to the capacity of the military "to adapt themselves into the field of environmental issues". ${ }^{14}$ Relatedly, it has been argued that the institutions that provide safety from environmental degradation (for example, the Environmental Protection Agency) and the institutions that provide safety from violence (the military) are fundamentally incompatible. The way they work and the means they employ are in direct opposition to each other: the military operates secretively, whereas the work of environmental protection agencies is open and deliberately accessible as they actively seek to inform and educate the public. ${ }^{15}$ Generally speaking, all critics of defence environmental security agree that this concept blurs the fact that the world's militaries are a leading cause of environmental degradation. ${ }^{16}$ Another such unifying criticism would be that it is questionable whether something qualifies as a security issue simply by virtue of being of interest to the agencies of the security establishment.

\section{Environmental conflict}

The security equation is more readily visible in the case of the environmental conflict thesis, particularly if we accept that "[t]here are two ways of expanding the concept of security. Either other fields link to the military, or they are equivalent to military problems". ${ }^{17}$ The idea that environmental issues may lead to violent conflict falls squarely into the first of these definitions, where we find yet another role for the military in the environmental security debate.

\footnotetext{
${ }^{10}$ Floyd, "Typologies of securitisation and desecuritisation”.

${ }^{11}$ Dabelko and Simmons, "Environment and Security", 137.

${ }^{12}$ Deibert, “From Deep Black to Green?”, 29.

${ }^{13}$ Floyd, "Towards a consequentialist evaluation of security”, 345-6.

${ }^{14}$ Käkönen, Green security or Militarised environment, 2.

${ }^{15}$ Deudney, "The Case against Linking Environmental Degradation and National Security", 465.

${ }^{16}$ Finger, "The military, the nation state and the environment".

${ }^{17}$ Wæver, "Concepts of security", 45 (emphasis in original).
} 
The idea that environmental issues may lead to violent conflict has received much attention in the environmental security literature and today several competing approaches to environmental conflict exist. The most prolific of these focuses on the role of environmental scarcity as an independent variable in violent conflict. This thesis has most prominently been developed by the so-called Toronto Group under the leadership of Thomas Homer-Dixon. Since 1989, this group has conducted a series of case studies (including in Mexico, Pakistan, Gaza, Rwanda and South Africa), and developed the thesis that when scarcity of renewable resources (such as cropland and river water) interacts with harsh social effects (for example, population displacement or economic decline) it can lead to intrastate conflict. ${ }^{18}$ In this formulation, the concept of environmental scarcity is very broadly construed. Thus Homer-Dixon interprets, "all types of environmental depletion or damage as various forms of scarcity of renewable resources. Deforestation increases the scarcity of forest resources, water pollution increases the scarcity of clean water, and climate change increases the scarcity of regular patterns of rainfall and temperature on which farmers rely". ${ }^{19}$ A key concept in Homer-Dixon's work on scarcity-induced environmental conflict is that of "resource capture", the idea that "environmental scarcity encourages powerful groups to capture valuable environmental resources and prompts marginal groups to migrate to ecologically sensitive areas. These two processes in turn reinforce environmental scarcity and raise potential for social instability." 20

I __ The Toronto group's scarcity thesis has been influential both inside and outside of the academy. In 1994, after the well-known travel writer Robert Kaplan used the Toronto Group's thesis in an essay for The Atlantic Monthly that proclaimed the environment as being "the national security issue of the early twenty-first century $^{\prime 21}$, Homer-Dixon was invited to brief Vice President Gore twice. ${ }^{22}$ The first briefing was on the scarcity thesis in general, the second focused specifically on environmental problems in China. Although Gore had both a long-standing interest in environmental issues and - like others- a need to explain and understand the interstate conflicts characteristic of the early 1990s, short of rhetorical implementation of scarcity arguments, little was done in actual policymaking terms in response to the environmental conflict thesis. ${ }^{23}$

| _ In the academic world of environmental security, however, engagement with the Toronto Group's scarcity thesis is an ongoing process. Since it was first enunciated, the Toronto Group's theory has been criticised for offering little of novel value for the role and definition of scarcity as an independent variable and for the choice of case studies. ${ }^{24}$ The list goes on. Testimony to the contentiousness of the

\footnotetext{
${ }^{18}$ Homer-Dixon, Environment, Scarcity, and Violence, 177.

${ }^{19}$ Ibid,9.

${ }^{20}$ Homer -Dixon, “The Project on Environment, Population and Security”, 46.

${ }^{21}$ Kaplan, "The Coming Anarchy”, 190.

${ }^{22}$ It should be noted that Homer-Dixon had been in contact with policymakers in Washington before February 1994. For example, already in 1992, he briefed a national security meeting under the auspices of P.J. Simmons (who worked at that time at the National Security Council's Global Environmental Affairs Directorate and the National Security Archive and, in autumn 1994, went on to direct the Center for Environmental Security and Change, created within the Woodrow Wilson Center for Scholars). However, it was not till after the publication of Kaplan's "The Coming Anarchy" that Homer-Dixon was contacted by Al Gore's staff. This information is taken from an interview by the author with Homer-Dixon in July 2005.

${ }^{23}$ Floyd, "Typologies of Securitisation and Desecuritisation”, 339.

${ }^{24}$ Levy, "Is the Environment a National Security issue?”; Peluso and Watts, "Violent Environments”, Gleditsch, "Armed Conflict and the Environment"
} 
thesis are also the debates between Homer-Dixon and his critics in the pages of the most renowned environmental security journal, the Woodrow Wilson Center's Environmental Change and Security Project's annual report. Above all, the contentiousness is visible in the fact that a number of rival environmental conflict theses have emerged, all of which are developed in explicit opposition to the environmental scarcity thesis.

I _ One of these rival theses is the idea that it is not scarcity that leads to civil conflict, but its opposite, resource abundance. The so-called "honey pot" thesis holds that it is an abundance of valuable resources (such as minerals, gem stones or oil) that makes people fight. ${ }^{25}$ Whilst the honey pot thesis seems intuitively compelling, proponents of the environmental scarcity thesis point out that the resource abundance thesis ultimately collapses into the scarcity thesis as locally abundant resources are only valuable because they are scarce on the global scale. ${ }^{26}$ Related to that, they emphasize that "the logic of the honey pot clearly applies more to situations in which initially abundant resources become increasingly scarce over time. [...] As natural resources are consumed or degraded at unsustainable rates, their value increases and rival social groups confront greater incentives to seize them." ${ }^{27}$

I ___ Another rival theory comes from political ecologists who argue that "rather than presuming or starting with scarcity or abundance, analysis of these cases of violence should begin with the precise and changing relations between political economy and mechanisms of access, control, and struggle over environmental resources. Scarcity and abundance are historically produced expressions of such relations, and as such should not be the starting point of analysis". ${ }^{24}$ These scholars take issue with the Toronto Group's interpretation of environmental scarcity as being so all-encompassing that it conflates distinct processes into one phenomenon. In the words of one proponent, "by adding the social distribution of resources into the definition of environmental scarcity, Homer-Dixon de facto creates a link to conflict, since political conflict often revolves around issues of resource control. This is the main tool by which he is able to force very disparate conflictual situations into his universalizing model but the result is a model so inclusive as to be banal". ${ }^{25}$ Needless to say, scarcity theorists have objected to these assertions. ${ }^{26}$

I __ Noticeable about this later approach is that, unlike other environmental conflict theories, it is not concerned with finding triggers of environmental conflict; rather political ecologists are concerned with "the production, enactment, and representation of violence against humans in relation to environment" ${ }^{27}$ As such, these analysts move away from a concern with the security of states and towards a human-centric interpretation of environmental security, emphasising that the state is not always the appropriate provider of security, but can instead be the source of insecurity and violence for human beings - a belief shared by a number of so-called critical approaches to security.

\section{The human security approach to environmental security}

\footnotetext{
${ }^{25}$ De Soysa, "The Resource Curse”; Collier and Hoeffler, Greed and Grievance in Civil War.

${ }^{26}$ Kahl, States, Scarcity and Civil Strife in the Developing World, 18.

${ }^{27}$ Ibid, 19.

${ }^{24}$ Peluso and Watts, Violent Environments: Responses, 93.

${ }^{25}$ Hartmann "Population, Environment and Security: A new Trinity” 117

${ }^{26}$ Kahl, Review of Violent Environments; Homer-Dixon, Debate on Violent Environments.

${ }^{27}$ Peluso and Watts, "Violent Environments”, 26.
} 
That the individual should be the focus of security is most prominently advocated in the 1994 Human Development Report that laid the groundwork for the concept of human security. "Human security can be said to have two main aspects. It means, first, safety from such chronic threats as hunger, disease and repression. And second, it means protection from sudden and hurtful disruptions in the patterns of daily lives". ${ }^{28}$ In this definition thus, human security is about the daily insecurity of people caused not only by conflict, but also by the sheer living conditions of the most disadvantaged. In the academic literature, there is considerable debate whether human security should be about the first of these, "freedom from fear", only or whether it should also include "freedom from want". The UNDP report identifies some seven different "domains" of human security - environmental security (often in the form of the consequences of environmental disaster) is one of them. Here, clearly, the security equation does not include issues linking to the military, but rather situations that are so bad that they are equivalent to war.

I __ That the individual is the appropriate referent object (that which is to be secured) for environmental security has many proponents within the environmental security literature. These proponents usually position themselves in direct opposition to the various environmental conflict theses and also to the greening of defence and argue that, because environmental threats know no territorial boundaries, true environmental security can only be achieved if environmental security is moved out of the state-centric threat and defence nexus. Proponents of the human security approach to environmental security then focus on issues such as ecological interdependence, human rights, the impact of globalisation and the effect of Northern consumption patterns on the global South. ${ }^{29}$ For them, the nature of the threat stems from the dangers of long-term environmental degradation, such as global warming, ozone depletion, species extinction, pollution of air and water, and loss of biodiversity which are non-violent in character. In this approach, environmental security can be usefully defined as: "The process of peacefully reducing human vulnerability to human-induced environmental degradation by addressing the root causes of environmental degradation and human insecurity". ${ }^{30}$ Development in a sustainable form is a key issue of concern for proponents of this approach.

I _ Despite the intuitive appeal of the human security approach to environmental security, this approach - like human security in general - can be criticised for being too all-encompassing and for offering few realisable policy-making recommendations, therefore amounting to little more than a critique of the more mainstream approaches.

I ___ Another still more damning critique can be extrapolated from the work of Ole Wæver and his development of the influential securitisation approach, complete with the concept of de-securitisation. The securitisation approach holds that security is a speech act, that alone by uttering "security" something is being done. A securitising actor, by stating that a particular referent object is threatened in its existence, claims a right to extraordinary measures to ensure the referent object's survival. The issue is then moved out of the sphere of normal politics into the realm of emergency politics, where it is handled without the normal rules and regulations of policymaking. In this understanding then security is seen a self-referential practice that does not refer to objective security threats outside itself. Because of this, Wæver rejects all alternative

\footnotetext{
${ }^{28}$ UNDP, Human Development Report 1994, 23.

${ }^{29}$ See, for example, Dalby, Environmental Security.

${ }^{30}$ Barnett, The Meaning of Environmental Security, 129.
} 
formulations of security concerned with allegedly objective security threats and urges us to "give up the assumption that security is, necessarily, a positive phenomenon". ${ }^{31}$ Focus should be placed on de-securitisation instead; the process whereby securitisation is reversed and formerly securitised issues once again become issues of normal politics. To understand this emphasis on de-securitisation, it is vital to realise that for Wæver the presence of security does not mean the absence of insecurity; rather "insecurity is the situation when there is a threat and no defence against it; security is a situation with a threat and a defence against it”. ${ }^{32}$ In other words, both security and insecurity are inseparably tied to the threat-defence nexus and maximising security does not mean less insecurity. The only way to escape the threatdefence nexus is to achieve "a-security (a situation that has been desecuritised or never securitised)". ${ }^{33}$

\title{
Environmental peacemaking /environmental cooperation
}

Arguments for de-securitisation have been part of the environmental security debate from the start. The prominent economist and cornucopian Julian L. Simon, for example, maintained that the environmental security debate rests on false premises as there is simply no shortage of natural resources, at least not one that cannot be overcome by human ingenuity and technological innovation. A quote from his closing statement in a published debate with Myers from 1994 captures his position well:

\begin{abstract}
The standard of living has risen along with the size of the world's population since the beginning of recorded time. There is no convincing reason why these trends towards better life should not continue indefinitely. The key theoretical idea is this: The growth of population and of income create actual and expected shortages, and hence lead to price run-ups. A price increase represents an opportunity that attracts profit-minded entrepreneurs to seek new ways to satisfy shortages. Some fail, at costs to themselves. A few succeed, and the final result is that we end up better off than if the original shortage problem had never arisen. $^{34}$
\end{abstract}

In addition, Simon was a prominent sceptic of global warming and other, as he called them, "cousin scares", including acid rain and the destruction of the ozone layer. Not only did he question the scientific evidence supporting these and/or their suspected consequences for human well-being (for example, he queried the correlation between increased risk of skin cancer and heightened ozone levels), he was also adamant that "[...] we now have large and ever-increasing capabilities to reverse such trends if they are proven to be dangerous, and at costs that are manageable." 35 Although Simon himself died in 1998, his ideas live on in the debate surrounding global warming. In particular, Simon's work has been instrumental to that of the self-styled "sceptical environmentalist” Adjunct Professor at the Copenhagen Business School Bjørn

\footnotetext{
${ }^{31}$ Waever, "Securitization and Desecuritization”, 57.

${ }^{32}$ Wæver, "Securitisation: Taking stock of a research programme in Security Studies", 13.

33 "A-security ... is simply not phrased in these terms, it is not a question of being secure or not, and there is not a perception of existential threats being present”. Ibid., 13.

${ }^{34}$ Simon, “Closing statement by Julian Simon”, 159.

${ }^{35}$ Simon, "Pre-Debate Statement: Julian Simon”, 19.
} 
Lomborg who, in 2004, was included in Time Magazine's list of the world's 100 most influential people. ${ }^{40}$

| _ In recent years, a different approach to environmental security that concerns itself with de-securitisation has emerged. Thus an increasing number of scholars have focused on environmental degradation's potential to lead to environmental cooperation and ultimately peace, instead of its role in triggering violent conflict. ${ }^{36}$ There are three ways in which environmental cooperation can be linked to peacemaking. ${ }^{37}$ The first of these concerns the possibility of environmental cooperation in areas with environmental conflicts. The idea is that environmentally induced conflict can be turned around through transboundary natural resource management/transboundary conservation initiatives. One example where a transboundary protected area (also known as "Peace Park") has successfully curbed environmentally induced conflict and fostered conservation is that of the Cordillera del Cóndor Peace Park established in 1998 between Peru and Ecuador. ${ }^{38}$

| __ The second way in which environmental cooperation has been linked to peace building is the idea that joint environmental concerns can lead to dialogue between conflicting governments, which may then spill-over into other areas. One candidate for proponents of this theory is the proposed "Siachen Peace Park" in the Siachen Glacier region of northern Kashmir where India and Pakistan have been at war since 1984. The Siachan conflict zone is the highest war zone in the world, posing unprecedented logistical, financial and physical strain on both armies. The conflict itself, coupled with the presence of the military in the area, poses unprecedented destruction to this unique ecosystem. According to retired Indian mountaineer Aamir Ali, who first suggested this idea, a Siachen Peace Park

[...] would enable both armies to withdraw under conditions of honour and dignity; it would not prejudice their positions on Kashmir as a whole; it would stop further degradation of a magnificent mountain area; it would save thousands of lives and billions of rupees; it would heal a running sore in the Kashmir imbroglio. ${ }^{39}$

The third environmental cooperation thesis holds that sustainable development is a necessary requirement for peace. This is the idea that even in conflicts where

40 According to Lomborg's website (FAQs section, http://www.lomborg.com/faq/?PHPSESSID=3a0ea70f8f278f3052997758b1645a6f ), his connection with Simon came about as follows: "It all started in 1997, when Bjorn Lomborg read a Wired Magazine interview with economist Julian Simon claiming that the environment - contrary to common understanding - was getting better, not worse. Lomborg thought this had to be incorrect ("right wing, American propaganda”). Looking for new ways to get his students involved, in the fall of 1997 he organised a study group with some of his top students to prove Simon wrong. Much to everyone's surprise, much (though definitely not everything) of what Simon said was right. Thus the group set out to write about their results in op-eds in Denmark's leading newspaper, Politiken. They published four lengthy articles with fifty footnotes in each, sparking a firestorm debate spanning over 400 articles in all the major metropolitan newspapers. The articles led to the publication of a book in Danish later that year and to The Skeptical Environmentalist in 2001.”

${ }^{36}$ Conca and Dabelko, Environmental Peacemaking; Ali, Peace Parks: Conservation and Conflict Resolution; Matthew, Halle and Switzer, Conserving the Peace: Resources, Livelihoods and Security.

${ }^{37}$ Carius, Environmental Peacebuilding: Conditions for Success, 61-4.

${ }^{38}$ UNEP, Global Transboundary Protected Areas Network, “Cordillera del Cóndor Transboundary Protected Area”.http://www.tbpa.net/case_01.htm

${ }^{39}$ Ali, “Siachen Peace Park: Solution to Half-Century of International Conflict”, 318. 
transboundary environmental problems are not the source of the conflict, sustainable peace cannot ensue without the resolution of these vital issues. The empirical example often cited in connection with this third thesis is that of water in the Israel/Palestine conflict, whereby it is believed that without a sustainable and joint water policy sustainable peace in this water scarce region cannot be achieved. ${ }^{40}$

| ___ Noticeable about the environmental cooperation literature is that although proponents are clearly excited about the possibilities for environmental cooperation leading to peace, all seem wary of overstating the casual linkages between environmental cooperation and peace. Much of the environmental cooperation literature is thus conceived as a normative effort. In the words of one proponent:

As scholars, we must identify the pieces missing from the environment conflict and cooperation puzzle and examine the gaps that inhibit political responses. We must move beyond the false dichotomy between scarcity and abundance. We must push forward with the growing effort to invert the conflict thesis and look at environmental pathways to confidence building and peacemaking. [...] Instead of merely reacting to the symptoms of environmental-conflict linkages, they should proactively extinguish hotspots by bolstering confidence and building cooperation. ${ }^{41}$

Although, the case of environmental peacemaking suggests that de-securitisation can be a more apt solution to environmental problems then securitisation, this is not always and necessarily the case, after all, de-securitisation does not always lead to the politicisation of environmental issues. Instead, after being de-securitised, environmental issues may drop from the mainstream policymaking agenda altogether. A case in point would be the fate of US environmental security under the current Bush administration, which saw the rolling back of its predecessor's environmental security initiatives, without any politicisation of said issues. ${ }^{42}$

\section{Climate security}

The connection between global warming and security has given renewed impetus to the environmental security debate. Far from having had a unifying effect, however, the divisions between proponents of environmental security remain and "climate security" has simply become integrated into the various approaches of environmental security. In 2007, for example, eleven retired US army generals and admirals, plus former Undersecretary of Defense for Environmental Security (1993-2000) Sherri W. Goodman, issued a report titled National Security and the Threat of Climate Change. This publication sits squarely with the old "greening of defence" approach. Thus, on the one hand, it highlights the role of the defence and intelligence community in this new area, for instance, through environmental disaster prevention and relief; it even suggests a linkage between climate change and the manifestation of terrorism. On the other, it focuses on the consequences of climate change for the US national security establishment; for example, there is concern for DoD installations situated in areas that would be affected by sea level rise. The message is clear, climate security should

\footnotetext{
${ }^{40}$ Carius, "Environmental Peacebuilding: Conditions for Success”, 62.

${ }^{41}$ Dabelko, "Next steps for Environment, Population, and Security", 4.

${ }^{42}$ Floyd, "Towards a consequentialist evaluation of security", 47-8.
} 
be recognised as a threat to national security and the military has an important role to play in it.

| Climate change also features prominently in the environmental conflict literature and within the human security approach to environmental security. The former is concerned with climate change's potential to bring about violent conflict. Homer-Dixon, for example, warns that, "Climate change will help produce the kind of military challenges that are difficult for today's conventional forces to handle: insurgencies, genocide, guerrilla attacks, gang warfare and global terrorism."43 Proponents of the human security approach, on the other hand, stress ecological interdependence and climate change's potential to impede development, thereby increasing inequality. For instance, the 2007-08 UN Human Development Report, Fighting Climate Change: Human solidarity in a divided World, argues that

climate change is a massive threat to human development and in some places it is already undermining the international community's efforts to reduce extreme poverty. [...] So we must see the fight against poverty and the fight against the effects of climate change as interrelated efforts. They must reinforce each other and success must be achieved on both fronts jointly. ${ }^{44}$

L__ Despite differences in opinion, proponents of all these approaches unquestionably promote climate change as a security issue. But, are they right in doing so? If we extrapolate from the regional examples analysed by proponents of environmental cooperation to the global level of analysis, then (greatly needed) cooperation on climate action seems much more likely in the absence of securitisation, and elevating climate change beyond the democratic realm loses its appeal. In order to consider all facets of the environmental security debate, it may be useful to make the case against climate security. One way of doing this is to highlight that climate change is not only an environmental security concern, but also an issue for economic security. As an economic security concern, climate change is addressed by the label "energy security". Proponents, notably the Bush administration, concern themselves with energy supply in the face of resource scarcity (e.g. finite oil resources) and with continuous energy sufficiency in a less carbon tolerant world. Although these issues are connected to the realisation that something needs to be done against climate change, the motivation for this does not arise from an interest in the environment or indeed human well-being; rather it is based on economic interests. Because of this, the solutions put forward are often far from environmentally friendly, and some, such as biofuels, even counterbalance reductions in green house gas (GHG) production. This counterbalancing can be both direct in that "changes in the carbon content of soils, or carbon stocks in forests and peat lands related to bioenergy production, might offset some or all of the GHG benefits" 45 , or indirect, for example, through the clearing of healthy forests to make way for biofuel plantations. ${ }^{46}$ In addition, it has been increasingly recognised that the Global North's amplified demand for biofuels is having adverse affects on food security in the Global South

\footnotetext{
${ }^{43}$ T. Homer-Dixon, “Terror in the Weather Forecast”, The New York Times, 24 April 2007; see also Schwartz and Randall “An Abrupt Climate Change Scenario”; Walker and King, The Hot Topic, 47-8.

${ }^{44}$ UNDP, Human Development Report 2007/2008, v \& vi.

${ }^{45}$ UN-Energy, "Sustainable Bioenergy a Framework for Decision Makers".

${ }^{46}$ Friends of the Earth Netherlands, "Policy, Practice, Pride and Prejudice”, July 2007. http://www.foeeurope.org/publications/2007/Wilmar_Palm_Oil_Environmental_Social_Impact.pdf
} 
and that this, coupled with social effects, increases the likelihood of environmentally induced conflict. ${ }^{47}$

| _ In summary, the securitisation of climate change is a double-edged sword. On the one hand, addressing climate change in the security mode raises one of the most pressing issues of our time to the top of the policymaking agenda and into individuals' consciousness. On the other hand, it can have adverse effects on both the natural environment and on the most disadvantaged members of international society.

\section{Conclusion}

"Environmental security" has a variety of meanings. Approaches to environmental security can complement one another, as do defence environmental security and the environmental conflict theses, when intelligence capabilities such as spy satellites are used to provide environmental data in conflict prone areas. But they can also be at odds with one another as are, for example, defence environmental security with its focus on national security and military readiness, and the human security approach to environmental security with its focus on sustainable development and the plight of the most disadvantaged.

| __ The linkage between climate change and security has been readily integrated into the existing dichotomies of the environmental security debate. As a result, for all those interested in climate security, it is vital to be aware of the connotations of this debate. This is not only because the literature might already hold some of the answers to the questions asked on the consequences of climate change, such as, do the environmental repercussions of climate change (drought, environmental migration, etc) lead to violent conflict? It is also because the literature shows that those that speak security to climate change often mean entirely different, even opposing things, and that - from an environmentalist perspective - climate security is not always a desirable concept as it may inhibit much needed cooperation between countries.

\section{References}

Ali, A. "A Siachen Peace Park: The Solution to Half-Century of International Conflict”. Mountain Research and Development 22, no. 4 (2002): 316-9.

Ali, S.H.,ed. Peace Parks: Conservation and Conflict Resolution. Cambridge: MIT Press, 2007.

Barnett, J. The Meaning of Environmental Security. London: Zed, 2001.

Buzan, B. People, States and Fear. $2^{\text {nd }}$ edition. London: Harvester Wheatsheaf, 1991.

Campbell, D. Writing Security. $2^{\text {nd }}$ edition. Minneapolis: The University of Minnesota Press, 1998.

${ }^{47}$ Ibid and Oxfam Briefing Note "Bio-fuelling poverty: Why the EU renewable-fuel target may be disastrous for poor people”, November 2007.

http://www.oxfam.org.uk/resources/policy/trade/downloads/bn_biofuels.pdf?m=234\&url=http://www. oxfam.org.uk/resources/policy/trade/downloads/bn_wdr2008.pdf 
Carius, A. Environmental Peacebuilding: Conditions for Success, Environmental Change and Security Program Report 12, Washington DC: Woodrow Wilson Center, 2006-07:_59- 75.

CNA Corporation, National Security and the Threat of Climate Change. Alexandria, VA: CNAC, 2007.

Collier, P. and A. Hoeffler. Greed and Grievance in Civil War. Centre for the Study of African Economies Working Paper. Oxford: Centre for the Study of African Economies, 2002-01.

Conca, K., A. Carius, and G.D. Dabelko. "Building Peace through Environmental Cooperation". In State of the World 2005: A Worldwatch Institute Report on Progress Toward a Sustainable Society, edited by M. Renner, H. French, and E. Assadourian. New York: W.W. Norton \& Company, 2005.

Conca, K. and G.D. Dabelko, eds. Environmental Peacemaking. Washington: Woodrow Wilson Center Press, 2002.

Dabelko, G.D. The Next Steps for Environment, Population, and Security. Environmental Change and Security Project Report 10. Washington DC: Woodrow Wilson Center, 2004: 4.

Dabelko, G.D. Tactical Victories and Strategic Losses: The Evolution of Environmental Security. Unpublished Doctoral Thesis, Graduate School of the University of Maryland, 2003.

Dabelko, G.D. and P.J. Simmons. "Environment and Security: Core Ideas and US Government Initiatives”. SAIS Review Winter-Spring (1997): 127-46.

Dalby, S. Environmental Security. Minneapolis: Minnesota Press, 2002.

Deibert, R.J. From Deep Black to Green? Military Monitoring of the Environment, Environmental Change and Security Program Report no. 2. Washington DC: Woodrow Wilson Center, 1996: 28.

De Soysa, I. "The Resource Curse: Are Civil Wars Driven by Rapacity or Paucity?” In Greed \& Grievance: Economic Agendas in Civil War, edited by M. Berdal and D. Malone: 113-35. Boulder: Lynne Rienner, 2000.

Deudney, D.H. “The Case against Linking Environmental Degradation and National Security”. Millennium: Journal of International Studies 19, no. 3 (1990): 461-76.

Finger, M. “The military, the nation state and the environment”. The Ecologist 21, no. $5,1991$.

Floyd, R. "Towards a consequentialist evaluation of security: Bringing together the Copenhagen School and the Welsh School of Security Studies". Review of International Studies 33, no. 2 (2007): 327-50. 
Floyd, R. "Typologies of Securitisation and Desecuritisation: The case of US environmental security 1993 - 2006”. Unpublished Doctoral thesis, University of Warwick, 2007.

Gleditsch, N.P. "Armed Conflict and the Environment” In Environmental Conflict edited by P.F. Diehl and N.P. Gleditsch: 521-72. Oxford: Westview Press, 2000.

Goodman, S. W. Military Capabilities and Possible Missions Related to Environmental Security. Environmental Change and Security Project Report no. 2. Washington DC: Woodrow Wilson Center, 1996.

Hartman, B. "Population, Environment and Security: A New Trinity". Environment and Urbanization10, no. 2 (October 1998).

Homer-Dixon, T. Debating Violent Environments, Environmental Change and Security Project Report no. 9. Washington DC: Woodrow Wilson Center, 2003: 8992.

Homer-Dixon, T. and V. Percival. "The Case of South Africa”. In Environmental Conflict, edited by P.F. Diehl and N.P. Gleditsch: 13-35. Oxford: Westview Press, 2001.

Homer-Dixon, T. Environment, Scarcity, and Violence. Princeton: Princeton University Press, 1999.

Homer-Dixon, T. The Project on Environment, Population and Security: Key Findings of Research, Environmental Change and Security Project Report no. 2. Washington DC: Woodrow Wilson Center, 1996: 45-8.

Homer-Dixon, T. "On the threshold: Environmental changes as causes of acute conflict”. International Security 16, no. 4 (1991): 76-116.

Kahl, C. States, Scarcity, and Civil Strife in the Developing World. Princeton: Princeton University Press, 2006.

Kahl, C. Review of Peluso and Watts: Violent Environments, Environmental Change and Security Project Report no. 8. Washington DC: Woodrow Wilson Center, 2002: $135-43$.

Käkönen, J. “Green security or militarized environment: An introduction” In Green security or Militarised environment, edited by Jyrki Käkönen. Aldershot: Dartmouth Publishing Company, 1994

Kaplan, R. "The Coming Anarchy.” Reprinted in The Geopolitics Reader, edited by G.O. Tuathail, S. Dalby and P. Routledge. London: Routledge, 1998.

Levy, M. “Is the Environment a National Security Issue?” International Security 20, no. 2 (1995): 35-62. 
Lomborg, B. The Skeptical Environmentalist. Cambridge: Cambridge University Press, 2001.

Matthew, R.A., M. Halle and J. Switzer. Conserving the Peace: Resources, Livelihoods and Security. Winnipeg: International Institute for Sustainable Development, 2002.

Myers, N. "Environment and Security”. Foreign Policy 74 (1989): 23-41.

Peluso, N. L. and M. Watts. Violent Environments: Responses, Environmental Change and Security Project Report no. 9. Washington DC: Woodrow Wilson Center, 2003: 93-6.

Peluso, N. L. and M. Watts. "Violent Environments". In Violent Environments, edited N. L. Peluso and M. Watts: 3-38. New York: Cornell, 2001.

Schwartz, P. and D. Randall. "An Abrupt Climate Change Scenario and Its Implications for United States National Security". Washington: Global Business Network, October 2003. http://www.edf.org/documents/3566_AbruptClimateChange.pdf

Simon, J. L. "Pre-debate Statement: Julian Simon". In Scarcity or Abundance? A debate on the Environment, edited by N. Myers and J.L. Simon. New York: Norton, 1994.

Simon, J. L. "Closing Statement by Julian Simon". In Scarcity or Abundance? A debate on the Environment, edited by N. Myers and J.L. Simon. New York: Norton, 1994.

Tuchman Mathews, J. "Redefining Security”. Foreign Affairs 68, no. 2 (1989): 16277.

Ullman, R. “Redefining Security”, International Security 8, no. 1 (1983): 129-53.

United Nations, Human Development Report: Fighting climate change: Human solidarity in a divided world, 2007-08. New York: UNDP, 2008. http://hdr.undp.org/en/media/hdr_20072008_en_complete.pdf

United Nations, Human Development Report: New dimensions of human security 1994. New York: UNDP, 1994. http://hdr.undp.org/en/media/hdr_1994_en.pdf

United Nations-Energy, "Sustainable Bioenergy: A Framework for Decision Makers". New York, United Nations-Energy, April 2007. http://esa.un.org/un-energy/index.htm

UNEP, World Commission on Protected Areas, Global Transboundary Protected Areas Network, "Cordillera del Cóndor Transboundary Protected Area”.http://www.tbpa.net/case_01.htm 
Walker, G. and D. King. The Hot Topic: How to tackle global warming and still keep the lights on. London: Bloomsbury Publishing, 2008.

Westing, A. H. "The Military Sector vis-à-vis the Environment”. Journal of Peace Research 25, no. 3 (1988): 257-64.

Westing, A. H. "The Environmental Component of Comprehensive Security". Security Dialogue 20, no. 2 (1989): 129-34.

Wæver, O. "Peace and Security - Two concepts and their relationship". In Analysis and Copenhagen Peace Research, edited by S. Guzzini and D. Jung: 51-65. London: Routledge, 2004.

Wæver, O. "Securitisation: Taking stock of a research programme in Security Studies”. Unpublished manuscript, University of Copenhagen, 2003.

Wæver, O. “Concepts of Security”. PhD Thesis, Copenhagen University, 1997.

Wæver, O. "Securitization and Desecuritization". In On Security, edited by R.D. Lipschutz. New York: Columbia University Press, 1995. 